\title{
Effects of Clove Oil Anaesthesia on European Catfish (Silurus glanis L.)
}

\author{
J. VELÍŠEK ${ }^{1}$, T. WLASOW ${ }^{2}$, P. GOMULKA ${ }^{2}$, Z. SVOBODOVÁ ${ }^{3,4}$, L. NOVOTNÝ ${ }^{4}$, E. ZIOMEK ${ }^{2}$ \\ ${ }^{1}$ Faculty of Agriculture, University of South Bohemia České Budějovice, Czech Republic \\ ${ }^{2}$ Faculty of Environmental Science and Fisheries, University of Warmia and Mazury Olsztyn, Poland \\ ${ }^{3}$ Research Institute of Fish Culture and Hydrobiology Vodňany, \\ University of South Bohemia České Budějovice, Czech Republic \\ ${ }^{4}$ University of Veterinary and Pharmaceutical Science Brno, Czech Republic
}

Received July 13, 2005

Accepted March 16, 2006

\begin{abstract}
Velíšek J., T. Wlasow, P. Gomulka, Z. Svobodová, L. Novotný, E. Ziomek: Effects of Clove Oil Anaesthesia on European Catfish (Silurus glanis L.). Acta Vet. Brno 2006, 75: 99-106.

The aim of the study was to investigate acute toxicity of clove oil for European catfish and, using values of haematological and biochemical profiles of blood and histological tissue examinations, to assess the effects of the fish exposure to that anaesthetic. Acute toxicity values of clove oil for European catfish found were $10 \mathrm{minLC} 5076.70 \mathrm{mg} \cdot \mathrm{l}^{-1} ; 10 \mathrm{minLC} 0.149 .60 \mathrm{mg} \cdot \mathrm{l}^{-1} ; 10 \mathrm{minLC} 99.9$ $118.50 \mathrm{mg} \cdot 1^{-1} ; 96 \mathrm{hLC} 5018.40 \mathrm{mg} \cdot \cdot^{-1} ; 96 \mathrm{hLC} 0.110 .70 \mathrm{mg} \cdot 1^{-1}$; and $96 \mathrm{hLC} 99.931 .90 \mathrm{mg} \cdot \cdot^{-1}$. Individual phases of anaesthesia and recovery were determined.

The 10-min exposure to clove oil at a concentration of $30 \mathrm{mg} \cdot \mathrm{l}^{-1}$ caused a significant $(p<0.05)$ increase in the concentration of triacylglycerols (TRIG), alanin aminotransferase (ALT) and decreased $(p<0.05)$ in mean corpuscular haemoglobin concentration (MCHC) immediately after anaesthesia. The leukocyte counts were significantly $(p<0.05)$ decreased 24 hours after anaesthesia. A significant $(p<0.05)$ decrease of percentage distribution lymphocytes was found immediately after anaesthesia. On the other hand, percentage and absolute count of myeloid cells were increased. Increased percentage count of eosinophils outlasted 24 hours after anaesthesia, absolute counts of these cells were consistents with control. Histological examination showed capillary ectasia of gill filaments immediately after clove oil anaesthesia. Twenty-four hours after anaesthesia, no ectasia was observed. No histopathological changes were demonstrated in other tissues following anaesthesia. Results of the examinations suggest that the use of clove oil at a concentration of $30 \mathrm{mg} \cdot \mathrm{l}^{-1}$ does not cause irreversible damage in European catfish.
\end{abstract}

Acute toxicity, haematological profile, biochemical profile of blood, histological examination of tissues

Anaesthesia, euthanasia and sedation of both wild and captive fish are common requirements in aquaculture and fisheries research around the world. These clinical techniques facilitate a wide variety of activities such as sorting, grading, transportation, tagging, gamete collections, health monitoring, weight/length measurements, blood sampling and invasive surgery to name a few. In all countries with animal care legislation, anaesthetics are routinely required during procedures that are deemed stressful or painful to fish.

The first reports of the use of eugenol containing products as fish anaesthetics date back more than 30 years (Endo et al. 1972) but the use of clove oil as an anaesthetic has been examined more closely in recent years (S oto and Burhanuddin 1995; Anderson et al. 1997; Munday and Wils on 1997; Keene et al. 1998; Peake 1998; Wagner et al. 2002; Iversen et al. 2003) and some variation in efficacy amongst fish species and life stages seems to occur.

Clove oil is derived from the stem, leaves and buds of the Eugenia caryophylatta tree, and it contains the active ingredient eugenol (4-allyl-methoxyphenol) in concentrations of 80 -

\footnotetext{
Address for correspondence:

Ing. Josef Velíšek

University of South Bohemia, Faculty of Agriculture

Department of Anatomy and Physiology of Farm Animals

Studentská 13

37005 České Budějovice, Czech Republic
}

Phone: +420732155886

Fax: + 420387772621

E-mail: velisek.j@centrum.cz

http://www.vfu.cz/acta-vet/actavet.htm 
$90 \%$ by volume. Eugenol is commonly used as an analgesic and antiseptic agent in human dentistry (Curtis 1990), and as a food additive for flavouring (Maura et al. 1989), and has been demonstrated to be extremely safe for humans (Miller et al. 1983). Eugenol can be used as an antimycotic agent in warm water fish aquaculture, but for salmonids it is highly toxic (Hussein et al. 2000).

Clove oil is used in the Czech Republic for short-term immobilization of fish before artificial spawning and whenever fish is handled outside water. The recommended concentration for anaesthetic purposes is $30 \mathrm{mg} \cdot \mathrm{l}^{-1}$ water bath (Svoboda and Kolářová 1999; Ha máč ková et al. 2001). At present, effects on clove oil on commercially produced fish are studied in a project regarding the application of principles of pharmacovigilance in aquaculture in the Czech Republic. In the first stage of the project, effects of 2phenoxyethanol on common carp (Velíšek and Svobodová 2004a) and rainbow trout (Velíšek and S vobodová 2004b) were studied. In the second stage of the project, effects of clove oil on rainbow trout (Velíšek et al. 2005a) and common carp (Velíšek et al. $2005 \mathrm{~b}$ ) were studied. The aim of the present study was to investigate acute toxicity of clove oil in European catfish and, on the basis of haematological indices, biochemical blood profile values and histological examinations, to assess the changes in the organism of European catfish induced by the anaesthetic.

\section{Materials and Methods}

In the study, clove oil marketed by the Kulich Company (Jan Kulich, Hradec Králové/Říčany, CR) in 10 ml and $50 \mathrm{ml}$ containers was used.

Acute toxicity of clove oil

Acute toxicity of clove oil was ascertained by the OECD 203 "Fish, acute toxicity test". For the $96 \mathrm{~h}$ and $10 \mathrm{~min}$ LC50 trials, European catfish of $4.50 \pm 1.07 \mathrm{~g}$ (mean $\pm \mathrm{SD}$ ) average weight and $83 \pm 25 \mathrm{~mm}$ average body length were used.

The 96-h LC50 test:

Experimental fish were exposed to concentrations 5, 10,16,18, 30 and $40 \mathrm{mg} \cdot \mathrm{l}^{-1}$ clove oil dissolved in diluting water $\left(\mathrm{pH} \quad 7.51\right.$; acid neutralization capacity - $\mathrm{ANC}_{4.5} 1.29 \mathrm{mmol} \cdot \mathrm{1}^{-1}$; total ammonia $0.03 \mathrm{mg} \cdot \mathrm{l}^{-1} ; \mathrm{NO}_{3}{ }^{-} 7.45 \mathrm{mg} \cdot \mathrm{l}^{-1} ; \mathrm{NO}_{2}^{-} 0.003 \mathrm{mg} \cdot \mathrm{l}^{-1} ; \mathrm{PO}_{4}^{3-} 0.02 \mathrm{mg} \cdot \cdot^{-1}$; chemical oxygen demand $\left.-\mathrm{COD}_{\mathrm{Mn}} 1.5 \mathrm{mg} \cdot \mathrm{l}^{-1}\right)$, and controls were placed in diluting water with no tested substance added. Ten piece European catfish were used for each concentration and for the control group. The fish and its behaviour, water temperature, $\mathrm{pH}$ and oxygen saturation were monitored throughout the tests at individual concentrations and in the control aquarium. Mean lethal concentration (96hLC50) and also 96hLC0.1 and 96hLC99.9 were calculated from mortality rates over the period of 96 hours.

The 10 -min LC50 test:

For $10 \mathrm{~min}$, the fish were exposed to concentrations of $30,50,60,80,90$, and $110 \mathrm{mg} \cdot \mathrm{l}^{-1}$ of clove oil dissolved in diluting water. Ten European catfish were used for each concentration and for the control group. Diluting water of the same parameters as in previous trials was used. During the 10 -min test period, changes in physiological parameters of fish and fish mortality figures were recorded, and after the European catfish had been moved to clean water, the time of their recovery and fish kill (in period $30 \mathrm{~min}$.) from anaesthesia was determined. Mean lethal concentrations (10minLC50) and also $10 \mathrm{minLC} 0.1$ and $10 \mathrm{minC} 99.9$ were calculated from mortality rates over the period of $10 \mathrm{~min}$.

In the tests, the onsets of individual phases of anaesthesia and recovery rates were studied. Evaluations were made in four consecutive phases (Thienpoint and Niemegeers 1965; Yoshikawa et al. 1988):

1. acceleration and subsequent deceleration of opercular movements, a partial loss of reactivity to external stimuli

2. loss of equilibrium, opercular movements very slow, fish still reactive to strong stimuli

3. total loss of reactivity, fish are lying at the tank bottom and do not respond to handling

4. complete cessation of opercular movements, fish die if left in the bath for too long.

Lethal concentration levels (LC50, LC0.1 and LC99.9) were determined by the probit analysis using EKO-TOX 5.1 software

Haematological and biochemical blood plasma profile after exposure to clove oil

For the haematological and biochemical blood profile tests and histological examination of tissues, European catfish of $94.90 \pm 55.23 \mathrm{~g}$ average weight and $253.0 \pm 74.60 \mathrm{~mm}$ average body length were used. A total of 40 fish divided into four groups were examined: Control I (before the anaesthetic administration), Experiment 
I [immediately after $10 \mathrm{~min}$ anaesthesia (exposure) at the concentration of $30 \mathrm{mg} \cdot \mathrm{l}^{-1}$ ], Experiment II (24 hrs after $10 \mathrm{~min}$ anaesthesia) and Control II (controls examined in parallel with Experiment II). The fish were anesthetized for $10 \mathrm{~min}$ by clove oil at a concentration of $30 \mathrm{mg} \cdot \mathrm{l}^{-1}$. Heparinized injection needles were used to take samples of blood from hearts of fish stunned by a blow with a blunt object over the head. To stabilize the blood samples, aqueous solution of heparin sodium salt at $0.01 \mathrm{ml}$ per $1 \mathrm{ml}$ blood was used (Svobodová et al. 1986).

Results of heamatological and biochemical examination were tested by the variance analysis using the Statistica 6.0 (ANOVA - Tuckey Test) software.

Haematological profile

The indices used to evaluate the haematological profile included the erythrocyte count (Er), haemoglobin concentration $(\mathrm{Hb})$, haematocrit $(\mathrm{PCV})$, mean erythrocyte volume (MCV), mean corpuscular haemoglobin concentration $(\mathrm{MCHC})$, mean corpuscular haemoglobin content $(\mathrm{MCH})$, leukocyte count (Leuko) and the differential leukocyte count (Leukogram). The procedures were based on Unified methods for haematological examination of fish (Svobodová et al. 1986).

Biochemical blood plasma profile

Blood plasma was obtained by centrifuging blood samples in a cooled centrifuge $\left(4^{\circ} \mathrm{C}, 837 \times g\right)$. Biochemical indicators determined in blood plasma included glucose (GLU), total protein (TP), albumins (ALB), total globulins (GLOB), ammonia $\left(\mathrm{NH}_{3}\right.$ ), triacylglycerols (TRIG), aspartate aminotransferase (AST), alanin aminotransferase (ALT), lactate dehydrogenase $(\mathrm{LDH})$, creatin kinase $(\mathrm{CK})$, calcium $\left(\mathrm{Ca}^{2+}\right)$ and inorganic phosphate (PHOS). For the biochemical analysis of blood plasma, the VETTEST 8008 analyzer (IDEXX Laboratories Inc. U.S.A.) manufactured by Medisoft was used. The analyzer uses dry chemical and colorimetric analysis techniques. Selective test discs (Multi-layer film slides, Kodak) are used for the evaluation by a laser reading bar codes.

Histological examination of tissues

After blood sampling, samples of gills, skin, liver, cranial and caudal kidney and spleen were taken for histological examinations. The samples were immediately fixed in $10 \%$ formaldehyde, drained and embedded in paraffin. Sections were made of the paraffin blocks and stained with haematoxylin-eosin.

\section{Results}

Acute toxicity of clove oil

During the 96-hour LC50 tests, the mean water temperature was $19.7-20.2{ }^{\circ} \mathrm{C}$, pH was $7.41-7.86$ and water oxygen levels were $76-96 \%$ saturation. On the basis of tests of acute toxicity to European catfish, the 96-hour lethal concentrations of clove oil were determined (see Table 1).

Autopsy performed after the acute toxicity test revealed increased amounts of watery mucus on body surfaces, and the gills were matt dark in colour. The body cavity contained excess moisture, and an increased injection of visceral vessels was also obtained.

During 10-min LC50 tests, water temperature was $19.8^{\circ} \mathrm{C}$, pH was 7.64 and water oxygen was at $95 \%$ saturation. On the basis of tests of acute toxicity to European catfish, the 10-min lethal concentrations of clove oil were determined (see Table 1).

Table 1. Acute toxicity of clove oil in European catfish

\begin{tabular}{|c|c|}
\hline Lethal concentration & Clove oil $\left(\mathrm{mg} \cdot \mathrm{l}^{-1}\right)$ \\
\hline $10 \operatorname{minLC} 0.1$ & 49.60 \\
\hline $10 \operatorname{minLC} 50$ & 76.70 \\
\hline $10 \operatorname{minLC} 99.9$ & 118.50 \\
\hline $96 \mathrm{hLC} 0.1$ & 10.70 \\
\hline $96 \mathrm{hLC} 50$ & 18.40 \\
\hline $96 \mathrm{hLC} 99.9$ & 31.90 \\
\hline
\end{tabular}

Effects of clove oil concentrations on the time of onset of anaesthesia, duration of its individual stages and the course of recovery are shown in Fig. 1.

Haematological blood profile after exposure to clove oil

Effects of clove oil on the haematological profile of European catfish are shown in Tables 2 and 3 . The 10 -min exposure to clove oil at a concentration of $30 \mathrm{mg} \cdot \mathrm{l}^{-1}$ caused a significant 


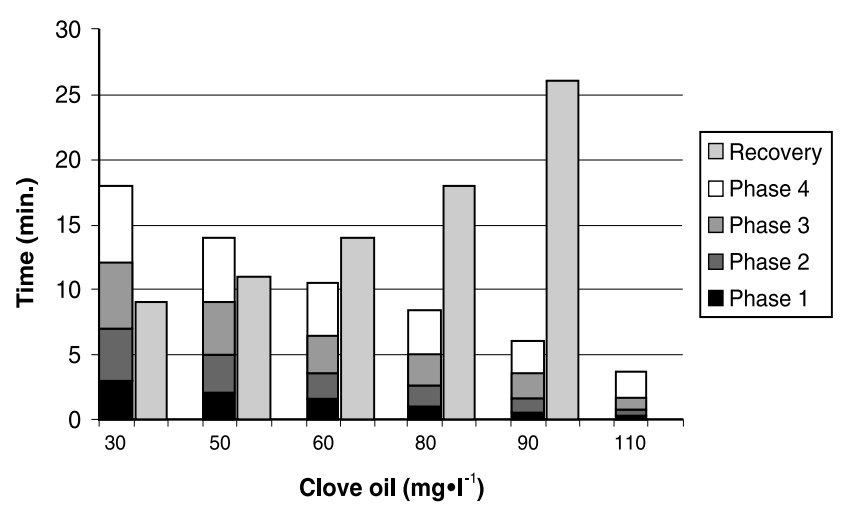

Fig. 1. Effects of clove oil concentrations on the onset of individual phases of anaesthesia and recovery in European catfish

$(p<0.05)$ decrease in mean corpuscular haemoglobin concentration immediately after anaesthesia. The leukocyte counts were significantly $(p<0.05)$ decreased $24 \mathrm{~h}$ after anaesthesia. A significant $(p<0.05)$ decrease of percentage count of lymphocytes was found immediately after anaesthesia. On the other hand, percentage and absolute counts of myeloid cells were increased. Increased percentage count of eosinophils outlasted $24 \mathrm{~h}$ after anaesthesia, absolute counts of these cells were consistent with controls. The rest of the indicators (Er, $\mathrm{Hb}, \mathrm{PCV}, \mathrm{MCV}$ and $\mathrm{MCH})$ were comparable in all groups.

Table 2. Effects of clove oil anaesthesia on haematological indices in European catfish

\begin{tabular}{|c|c|c|c|c|}
\hline Indicators & $\begin{array}{c}\text { Control I. } \\
\text { (before anaesthesia) } \\
\mathrm{x} \pm \mathrm{SD}(\mathrm{n}=10)\end{array}$ & $\begin{array}{c}\text { Experimental I } \\
\text { (immediately after } \\
\text { anaesthesia) } \\
\mathrm{x} \pm \mathrm{SD}(\mathrm{n}=10)\end{array}$ & $\begin{array}{l}\text { Experimental II } \\
(24 \text { hrs after } \\
\text { anaesthesia) } \\
x \pm S D(n=10)\end{array}$ & $\begin{array}{c}\text { Control II. } \\
\text { (after } 24 \text { hrs) } \\
x \pm \operatorname{SD}(n=10)\end{array}$ \\
\hline $\operatorname{Er}\left(\mathrm{T} \cdot \mathrm{l}^{-1}\right)$ & $0.82 \pm 0.23^{\mathrm{a}}$ & $0.83 \pm 0.29^{\mathrm{a}}$ & $0.73 \pm 0.16^{\mathrm{a}}$ & $0.76 \pm 0.25^{\mathrm{a}}$ \\
\hline $\mathrm{Hb}\left(\mathrm{g} \cdot \mathrm{l}^{-1}\right)$ & $38.54 \pm 6.84{ }^{a}$ & $34.92 \pm 4.11^{\mathrm{a}}$ & $42.96 \pm 6.74 \mathrm{a}$ & $39.51 \pm 5.89^{a}$ \\
\hline $\operatorname{PCV}\left(1 \cdot 1^{-1}\right)$ & $0.21 \pm 0.04^{\mathrm{a}}$ & $0.22 \pm 0.02^{\mathrm{a}}$ & $0.195 \pm 0.03^{\mathrm{a}}$ & $0.195 \pm 0.03^{a}$ \\
\hline $\operatorname{MCV}(\mathrm{fl})$ & $266.94 \pm 138.52^{\text {a }}$ & $269.48 \pm 147.40^{\text {a }}$ & $249.95 \pm 220.80^{\mathrm{a}}$ & $229.19 \pm 160.49^{a}$ \\
\hline $\mathrm{MCH}(\mathrm{pg})$ & $53.0 \pm 24.38^{a}$ & $47.09 \pm 23.60^{\mathrm{a}}$ & $59.88 \pm 18.11^{a}$ & $50.04 \pm 46.35^{\mathrm{a}}$ \\
\hline $\operatorname{MCHC}\left(\mathrm{g} \cdot \mathrm{l}^{-1}\right)$ & $177.56 \pm 31.42^{\mathrm{a}}$ & $157.56 \pm 24.50^{\mathrm{a}}$ & $215.41 \pm 30.86^{\mathrm{a}}$ & $171.67 \pm 37.66^{\mathrm{a}}$ \\
\hline Leuko $\left(\mathrm{G} \cdot \mathrm{1}^{-1}\right)$ & $20.40 \pm 4.04^{\mathrm{a}}$ & $14.0 \pm 5.86^{\mathrm{a}}$ & $9.20 \pm 6.59^{\mathrm{a}}$ & $14.0 \pm 7.50^{\mathrm{a}}$ \\
\hline
\end{tabular}

Groups with different alphabetic superscripts differ significantly at $p<0.05$ (ANOVA)

Biochemical blood plasma profile after exposure to clove oil

Effects of clove oil on the blood plasma biochemical profile of European catfish are given in Table 4. The 10-min exposure to clove oil at a concentration of $30 \mathrm{mg} \cdot \mathrm{l}^{-1}$ caused a significant $(p<0.05)$ increase in the concentration of triacylglycerols and alanine aminotransferase immediately after anaesthesia. Their values returned to physiological values within $24 \mathrm{~h}$. The rest of the indicators (GLU, TP, ALB, GLOB, NH 3 , AST, LDH, CK, $\mathrm{Ca}^{2+}$, PHOS) were comparable in all groups.

Histological examination of tissues

All specimens of European catfish showed capillary ectasia of gill filaments immediately after clove oil anaesthesia. Twenty-four hours after anaesthesia, no ectasia was observed. 
Table 3. Effects of clove oil anaesthesia on differential leukocyte counts in European catfish

\begin{tabular}{|c|c|c|c|c|c|}
\hline Indicators & & $\begin{array}{c}\text { Control I. } \\
\text { (before anaesthesia) } \\
\mathrm{x} \pm \mathrm{SD}(\mathrm{n}=10)\end{array}$ & $\begin{array}{c}\text { Experimental I } \\
\text { (immediately after } \\
\text { anaesthesia) } \\
\mathrm{x} \pm \mathrm{SD}(\mathrm{n}=10)\end{array}$ & $\begin{array}{l}\text { Experimental II } \\
(24 \mathrm{hrs} \text { after } \\
\text { anaesthesia) } \\
\mathrm{x} \pm \mathrm{SD}(\mathrm{n}=10)\end{array}$ & $\begin{array}{c}\text { Control II. } \\
\text { (after } 24 \mathrm{hrs)} \\
\mathrm{x} \pm \mathrm{SD}(\mathrm{n}=10)\end{array}$ \\
\hline \multirow[t]{2}{*}{ Lymphocytes } & $\%$ & $66.20 \pm 10.27^{\mathrm{a}}$ & $43.75 \pm 7.49^{\mathrm{a}}$ & $73.00 \pm 10.40^{a}$ & $78.70 \pm 7.06^{\mathrm{a}}$ \\
\hline & $\mathrm{G} \cdot \mathrm{l}^{-1}$ & $13.50 \pm 2.09^{\mathrm{a}}$ & $6.13 \pm 1.05^{\mathrm{a}}$ & $6.71 \pm 0.96^{\mathrm{a}}$ & $11.04 \pm 1.00^{\mathrm{a}}$ \\
\hline \multirow[t]{2}{*}{ Monocytes } & $\%$ & $0.90 \pm 1.22^{\mathrm{a}}$ & $0.35 \pm 0.78^{a}$ & $0.30 \pm 0.33^{\mathrm{a}}$ & $0.45 \pm 0.79^{a}$ \\
\hline & $\mathrm{G} \cdot \mathrm{l}^{-1}$ & $0.18 \pm 0.25^{\mathrm{a}}$ & $0.05 \pm 0.09^{\mathrm{a}}$ & $0.03 \pm 0.03^{\mathrm{a}}$ & $0.06 \pm 0.11^{\mathrm{a}}$ \\
\hline \multirow{2}{*}{$\begin{array}{l}\text { Neutrophil } \\
\text { granulocytes } \\
\text { segments }\end{array}$} & $\%$ & $17.0 \pm 6.54^{\mathrm{a}}$ & $16.75 \pm 5.37^{\mathrm{a}}$ & $6.10 \pm 3.90^{b}$ & $5.35 \pm 2.34^{b}$ \\
\hline & $\mathrm{G} \cdot \mathrm{l}^{-1}$ & $3.47 \pm 1.33^{a}$ & $2.35 \pm 0.75^{a}$ & $0.56 \pm 0.36^{b}$ & $0.75 \pm 0.33^{b}$ \\
\hline \multirow{2}{*}{$\begin{array}{l}\text { Neutrophil } \\
\text { granulocytes } \\
\text { rods }\end{array}$} & $\%$ & $10.95 \pm 8.64^{\mathrm{a}}$ & $29.25 \pm 6.55^{b}$ & $13.90 \pm 5.42^{\mathrm{a}}$ & $13.65 \pm 6.57^{\mathrm{a}}$ \\
\hline & $\mathrm{G} \cdot \mathrm{l}^{-1}$ & $2.23 \pm 1.76^{\mathrm{a}}$ & $4.09 \pm 0.92 \mathrm{~b}$ & $1.28 \pm 0.50^{\mathrm{a}}$ & $1.91 \pm 0.92^{\mathrm{a}}$ \\
\hline \multirow{2}{*}{$\begin{array}{l}\text { Developmental } \\
\text { phases - myeloid } \\
\text { sequence }\end{array}$} & $\%$ & $1.40 \pm 1.24^{\mathrm{a}}$ & $2.25 \pm 2.16^{\mathrm{a}}$ & $1.20 \pm 0.64^{\mathrm{a}}$ & $0.90 \pm 0.58^{\mathrm{a}}$ \\
\hline & $\mathrm{G} \cdot \mathrm{l}^{-1}$ & $0.27 \pm 0.23^{a}$ & $0.32 \pm 0.30^{a}$ & $0.11 \pm 0.21^{a}$ & $0.13 \pm 0.10^{a}$ \\
\hline \multirow[t]{2}{*}{ Eosinophils } & $\%$ & $2.80 \pm 2.30^{\mathrm{a}}$ & $7.65 \pm 4.27^{b}$ & $5.4 \pm 3.25^{b}$ & $0.85 \pm 0.95^{\mathrm{a}}$ \\
\hline & $\mathrm{G} \cdot 1^{-1}$ & $0.57 \pm 0.47^{\mathrm{a}}$ & $1.07 \pm 0.98^{\mathrm{a}}$ & $0.50 \pm 0.41^{\mathrm{a}}$ & $0.11 \pm 0.21^{\mathrm{a}}$ \\
\hline \multirow[t]{2}{*}{ Basophils } & $\%$ & $0.75 \pm 1.15^{\mathrm{a}}$ & $0.0 \pm 0.0^{\mathrm{a}}$ & $0.10 \pm 0.20^{\mathrm{a}}$ & $0.10 \pm 0.30^{\mathrm{a}}$ \\
\hline & $\mathrm{G} \cdot \mathrm{l}^{-1}$ & $0.15 \pm 0.23^{\mathrm{a}}$ & $0.0 \pm 0.0^{\mathrm{a}}$ & $0.0 \pm 0.01^{\mathrm{a}}$ & $0.01 \pm 0.04^{\mathrm{a}}$ \\
\hline
\end{tabular}

Groups with different alphabetic superscripts differ significantly at $p<0.05$ (ANOVA).

Table 4. Effects of clove oil anaesthesia on biochemical indices of blood plasma in European catfish

\begin{tabular}{|c|c|c|c|c|}
\hline Indicators & $\begin{array}{c}\text { Control I. } \\
\text { (before anaesthesia) } \\
\mathrm{x} \pm \mathrm{SD}(\mathrm{n}=10)\end{array}$ & $\begin{array}{c}\text { Experimental I } \\
\text { (immediately after } \\
\text { anaesthesia) } \\
\mathrm{x} \pm \mathrm{SD}(\mathrm{n}=10)\end{array}$ & $\begin{array}{c}\text { Experimental II } \\
(24 \mathrm{hrs} \text { after } \\
\text { anaesthesia) } \\
\mathrm{x} \pm \mathrm{SD}(\mathrm{n}=10)\end{array}$ & $\begin{array}{c}\text { Control II. } \\
\text { (after } 24 \text { hrs) } \\
x \pm \operatorname{SD}(n=10)\end{array}$ \\
\hline GLU $\left(\mathrm{mmol} \cdot \mathrm{l}^{-1}\right)$ & $7.24 \pm 2.63^{\mathrm{a}}$ & $6.92 \pm 1.98^{\mathrm{a}}$ & $4.94 \pm 1,01^{\mathrm{a}}$ & $5.01 \pm 1.90^{\mathrm{a}}$ \\
\hline $\mathrm{TP}\left(\mathrm{g} \cdot \mathrm{l}^{-1}\right)$ & $35.30 \pm 4.0^{\mathrm{a}}$ & $34.80 \pm 1.60^{a}$ & $36.30 \pm 2.15^{\mathrm{a}}$ & $32.50 \pm 2.70^{a}$ \\
\hline $\operatorname{ALB}\left(g \cdot l^{-1}\right)$ & $3.80 \pm 1.83^{\mathrm{a}}$ & $3.50 \pm 0.81^{\mathrm{a}}$ & $3.90 \pm 1.30^{\mathrm{a}}$ & $2.70 \pm 1.27^{\mathrm{a}}$ \\
\hline $\operatorname{GLOB}\left(\mathrm{g} \cdot \mathrm{l}^{-1}\right)$ & $31.60 \pm 2.11^{\mathrm{a}}$ & $31.70 \pm 0.90^{\mathrm{a}}$ & $32.40 \pm 1.20^{\mathrm{a}}$ & $29.60 \pm 1.69^{\mathrm{a}}$ \\
\hline $\mathrm{NH}_{3}\left(\mu \mathrm{mol} \cdot 1^{-1}\right)$ & $931.60 \pm 68.09^{\mathrm{a}}$ & $949.21 \pm 78.44^{\mathrm{a}}$ & $923.41 \pm 81.55^{\mathrm{a}}$ & $936.79 \pm 76.11^{\mathrm{a}}$ \\
\hline TRIG $\left(\mathrm{mmol} \cdot \mathrm{l}^{-1}\right)$ & $1.18 \pm 0.39^{\mathrm{a}}$ & $1.90 \pm 0.51^{\mathrm{b}}$ & $0.94 \pm 0.39^{\mathrm{a}}$ & $1.07 \pm 0.25^{\mathrm{a}}$ \\
\hline $\operatorname{AST}\left(\mu \mathrm{kat} \cdot 1^{-1}\right)$ & $7.43 \pm 0.60^{\mathrm{a}}$ & $7.56 \pm 0.66^{\mathrm{a}}$ & $7.50 \pm 0.59^{\mathrm{a}}$ & $7.53 \pm 0.71^{\mathrm{a}}$ \\
\hline $\operatorname{ALT}\left(\mu \mathrm{kat} \cdot \mathrm{l}^{-1}\right)$ & $0.19 \pm 0.09^{\mathrm{a}}$ & $0.30 \pm 0.11^{\mathrm{b}}$ & $0.17 \pm 0.13^{\mathrm{a}}$ & $0.18 \pm 0.10^{\mathrm{a}}$ \\
\hline $\mathrm{LDH}\left(\mu \mathrm{kat} \cdot \mathrm{l}^{-1}\right)$ & $8.96 \pm 4.18^{\mathrm{a}}$ & $9.06 \pm 5.44^{\mathrm{a}}$ & $10.07 \pm 6.79^{a}$ & $8.89 \pm 6.65^{\mathrm{a}}$ \\
\hline $\mathrm{CK}\left(\mu \mathrm{kat} \cdot \mathrm{l}^{-1}\right)$ & $44.82 \pm 2.89^{\mathrm{a}}$ & $43.21 \pm 3.06^{\mathrm{a}}$ & $44.99 \pm 3.26^{\mathrm{a}}$ & $44.08 \pm 4.34^{\mathrm{a}}$ \\
\hline $\mathrm{Ca}^{2+}\left(\mathrm{mmol} \cdot \mathrm{l}^{-1}\right)$ & $2.30 \pm 0.21^{\mathrm{a}}$ & $2.21 \pm 0.15^{\mathrm{a}}$ & $2.13 \pm 0.12^{\mathrm{a}}$ & $2.08 \pm 0.08^{\mathrm{a}}$ \\
\hline PHOS $\left.\left(\mathrm{mmol}^{-1}\right)^{-1}\right)$ & $1.16 \pm 0.14^{\mathrm{a}}$ & $1.40 \pm 0.27^{\mathrm{a}}$ & $1.35 \pm 0.20^{\mathrm{a}}$ & $1.37 \pm 0.18^{\mathrm{a}}$ \\
\hline
\end{tabular}

Groups with different alphabetic superscripts differ significantly at $p<0.05$ (ANOVA).

No histopathological changes were demonstrated in other tissues (liver, skin, spleen, cranial and caudal kidneys) following anaesthesia.

\section{Discussion}

The generally reported clove oil concentration as a fish anaesthetic is $30 \mathrm{mg} \cdot \mathrm{l}^{-1}$ ( $\mathrm{S} \mathrm{v} \mathrm{ob} \mathrm{o} \mathrm{da}$ and Kolářová 1999). Waterstrat (1999) and Small (2003) reported $100 \mathrm{mg} \cdot \mathrm{l}^{-1}$ clove oil as a safe concentration for anaesthesia of the channel catfish (Ictalurus punctatus), adding 
that exposures longer than 15 min prolonged recovery times and increased mortality. The main advantages of clove oil are its low cost and relative safety to both fish and fish-handling humans.

Increasing the anaesthetic dose significantly decreased induction times and resulted in increased recovery times for fish. Similar findings have been reported for carp (En do et al. 1972; Hikasa et al. 1986), rainbow trout (Keene et al. 1998) and Atlantic salmon (Iversen et al. 2003). The effect of clove oil concentrations on induction and recovery times is shown in Fig. 1.

Haematological and biochemical profiles of blood can provide important information about the internal environment of the organism (Masopust 2000). Values determined in the present study suggest that internal organs and tissues of European catfish are not altered by clove oil anaesthesia. This conclusion was also confirmed by the result of histological examination of parenchymatous organs.

In our experiments with European catfish, a significant increase $(p<0.05)$ in blood plasma triacylglycerols and alanin aminotransferase immediately after the 10-min clove oil anaesthesia was observed. Increased triacylglycerols and alanin aminotransferase returned to physiological values within $24 \mathrm{~h}$ anaesthesia.

On the other hand, Velíšek et al. (2005ab) found changes in the concentration of glucose and inorganic phosphate in common carp (Cyprinus carpio), increased concentration of glucose, ammonia and a significant decrease in the aspartate aminotransferase in rainbow trout (Oncorhynchus mykiss) following clove oil anaesthesia.

In the study of anaesthetized common carp (Cyprinus carpio) and rainbow trout (Oncorhynchus mykiss), Velíšek et al. (2005ab) found no change on the haematological profile following clove oil anaesthesia. In our experiments with European catfish, a significant $(p<0.05)$ decrease in mean corpuscular haemoglobin concentration, percentage distribution of lymphocytes and increased percentage and absolute count of myeloid cells immediately after anaesthesia. A significantly $(p<0.05)$ decreased leukocyte count and increased percentage distribution of eosinophils $24 \mathrm{~h}$ after anaesthesia.

The disadvantage of clove oil is its relatively low therapeutic index, i.e. the ratio between the therapeutic and the toxic concentrations. The generally reported optimum ratio is 1:4 or higher (Svobodová and Vyku sová 1991). A comparison between the concentration used in a 10 -min anaesthesia of fish $\left(30 \mathrm{mg} \cdot \mathrm{l}^{-1}\right)$ and the $10 \mathrm{minLC} 50$ values found $\left(76.70 \mathrm{mg} \cdot \mathrm{l}^{-1}\right)$ suggests that the clove oil therapeutic index is $1: 2.6$. Results of our examinations suggest that the use of clove oil at a concentration of $30 \mathrm{mg} \cdot \mathrm{l}^{-1}$ does not cause irreversible damage in European catfish. According to Taylor and Robers (1999) clove oil is an efficient and relatively safe anaesthetic.

\section{Vliv anestetika hřebíčkového oleje na sumce velkého (Silurus glanis L.)}

Cílem práce bylo posoudit akutní toxicitu hřebíčkového oleje pro sumce velkého a pomocí hodnot hematologického vyšetření, biochemického profilu krve a histologického vyšetření tkání posoudit stav tkání sumce velkého po působení tohoto anestetika. Akutní toxicita hřebíčkového oleje pro sumce velkého byla následující: $10 \operatorname{minLC50} \quad 76,70 \mathrm{mg} \cdot \mathrm{l}^{-1}$; 10minLC0,1 49,60 mg $\cdot 1^{-1} ; 10 \mathrm{minLC} 99,9118,50 \mathrm{mg} \cdot \mathrm{l}^{-1} ; 96 \mathrm{hLC} 5018,40 \mathrm{mg} \cdot \mathrm{l}^{-1} ; 96 \mathrm{hLC} 0,1$ $10,70 \mathrm{mg} \cdot \mathrm{l}^{-1}$ a $96 \mathrm{hLC} 99,931,90 \mathrm{mg} \cdot \mathrm{l}^{-1}$. Byl popsán časový průběh anastézie a jejího odeznění.

Po $10 \mathrm{~min}$. anestézii hřebíčkovém oleji v koncentraci $30 \mathrm{mg} \cdot \mathrm{l}^{-1}$ bylo zaznamenáno významné zvýšení ( $\mathrm{p}<0,05)$ koncentrace triacylglycerolu (TRIG), alanin aminotransferázy $($ ALT) a signifikantní $(\mathrm{p}<0,05)$ snížení střední barevné koncentrace $(\mathrm{MCHC})$ ihned po anestézii. Počet leukocytů (Leuko) byl signifikantně $(p<0,05)$ snížen 24 hodin po anestézii. Procentuální zastoupení lymfocytů bylo signifikantně $(p<0,05)$ sníženo ihned po anestézii. 
Naproti tomu zastoupení myeloidních buněk se zvýšilo. Zvýšené procentuální zastoupení eosinofilních granulocytů přetrvalo i 24 hodin po anestézii, absolutní počet těchto buněk byl shodný s kontrolou. Histologické vyšetření ryb po anestézii prokázalo výskyt ektázií na žaberních lístcích, 24 hodin po anestézii ektázie nebyly prokázány. V ostatních tkáních (játra, kůže, slezina, kraniální a kaudální ledvina) nebyly zjištěny histopatologické změny. Výsledky ukázaly, že hřebíčkový olej v koncentraci $30 \mathrm{mg} \cdot \mathrm{l}^{-1}$ je pro sumce velkého bezpečný.

\section{Acknowledgements}

This study was supported by the USB RIFCH (Project No. MSM 6007665809), the Ministry of Agriculture Project NAZV QF3029 Harmonization with the EU in applying pharmacovigilance principles in aquaculture in the Czech Republic, the GACR 523/03/H076 Project and WM University in Olsztyn, Poland grant No. 0804 205. The authors appreciate the help provided by Prof. Jan Glogowski.

\section{References}

ANDERSON WG, MCKINLAY RS, COLAVECCIA M 1997: The use of clove oil as an anaesthetic for rainbow trout and its effects on swimming performance. North Am J Fish Managem 17: 301-307

CURTIS EK 1990: In pursuit of palliation: oil of cloves in the art of dentistry. Bull His Dentist 38: 9-14

ENDO T, OGISHIMA K, TANAKA H, OHSHIMA S 1972: Studies on the anaesthetic effect of eugenol in some freshwater fishes. Bull Japan Soc Sci Fish 38: 761-767

Fish, acute toxicity test. OECD guidelines for testing of chemicals. 1999 No. 203: 9 p.

HAMÁČKOVÁ J, SEDOVA JM, PJANOVA SV, LEPICOVA A 2001: The effect 2-phenoxyethanol, clove oil and Propiscin anaesthetics on perch (Perca fluviatilis) in relation to water temperature. Czech J Anim Sci 46: 469-473

HIKASA Y, TAKASE, K OGASAWARA T, OGASAWARA S 1986: Anaesthesia and recovery with tricaine methanesulfonate, eugenol and thiopental sodium in the carp, Cyprinus carpio. Japan J Vet Sci 48: 341-351

HUSSEIN MMA, WADA S, HATAI K, YAMAMOTO A 2000: Antimycotic activity of eugenol against selected water molds. J Aquat Animal Health $12: 224-229$

IVERSEN M, FINSTAD B, MCKINLAY RS, ELIASSEN RA 2003: The efficacy of metomidate, clove oil, AQUISTM and Benzoak1 as anaesthetics in Atlantic salmon (Salmo salar L.) smolts, and their potential stressreducing capacity. Aquaculture 221: 549-566

KEENE JL, NOAKES DLG, MOCCIA RD, SOTO CG 1998: The efficacy of clove oil as an anaesthetic for rainbow trout, Oncorhynchus mykiss (Walbaum). Aquaculture Res 29: 89-101

MAURA A, PINO A, RICCI R 1989: Negative evidence in vivo of DNA-damaging, mutagenic and chromosomal effects of eugenol. Mutation Res 227: 125-129

MASOPUST J 2000: Clinical biochemistry. (In Czech) Karolinium, Prague, 832 p.

MILLER EC, SWANSON AB, PHILLIPS DH, FLETCHER TL, LIEM A, MILLER JA 1983: Structure-activity studies of the carcinogenities in the mouse and rat of some naturally occurring and synthetic alkenylbenzene derivatives related to safrole and estragole. Cancer Res 43: 1123-1124

MUNDAY PL, WILSON SK 1997: Comparative efficacy of clove oil and other chemicals in anaesthetization of Pomacentrus amboinensis, a coral reef fish. J Fish Biol 51: 931-938

PEAKE S 1998: Sodium bicarbonate and clove oil as potential anaesthetics of nonsalmonid fishes. North Am J Fish Managem 18: 919-924

SMALL BC 2003: Anesthetic efficacy of methomidate and comparison of plasma cortisol responses to tricaine methanesulfonate, quinaldine and clove oil anesthetized channel catfish Ictalurus punctatus. Aquaculture 218: $177-185$

SOTO CG, BURHANUDDIN S 1995: Clove oil as a fish anaesthetic for measuring length and weight of rabbitfish (Siganus lineatus). Aquaculture 136: 149-152

SVOBODA M, KOLÁŔOVÁ J 1999: A survey of anaesthetics used in the fish farming. Health Protection of Fish - Proceedings of Conference Papers. Research Institute of Fish Culture and Hydrobiology Vodňany (In Czech) 49-72

SVOBODOVÁ Z, PRAVDA D, PALÁČKOVÁ J 1986: Unified methods of haematological examination of fish. Research Institute of Fish Culture and Hydrobiology, Vodňany. Methods No 22: 31 p.

SVOBODOVÁ Z, VYKUSOVÁ B 1991: Diagnostics, prevention and therapy of fish diseases and intoxications. Manual for International Training Course on Fresh-Water Fish Diseases and Intoxications. Research Institute of Fish Culture and Hydrobiology, Vodňany, $270 \mathrm{p}$.

TAYLOR PW, ROBERTS SD 1999: Clove oil: An alternative anaesthetic for aquaculture. North Am J Aquacul 61: $150-155$

THEINPOINT D, NIEMEGEERS CJE 1965: R 7464- a new potent anaesthetic in fish. Inter Zoo Yearbook 5: $202-205$ 
VELÍŠEK J, SVOBODOVÁ Z 2004a: Anaesthesia of common carp (Cyprinus carpio L.) with 2-phenoxyethanol: acute toxicity and effects on biochemical blood profile. Acta Vet Brno 73: 247-252

VELÍŚEK J, SVOBODOVÁ Z 2004b: Anaesthesia of rainbow trout (Oncorhynchus mykiss) with 2phenoxyethanol: acute toxicity and effects on biochemical blood profile. Acta Vet Brno 73: 378-384

VELÍŠEK J, SVOBODOVÁ Z, PIAČKOVÁ V 2005a: Effects of clove oil anaesthesia on rainbow trout (Oncorhynchus mykiss). Acta Vet Brno 74: 139-146

VELÍŠEK J, SVOBODOVÁ Z, PIAČKOVÁ V, GROCH L, NEPEJCHALOVÁ L 2005b: Effects of clove oil anaesthesia on common carp (Cyprinus carpio). Vet Med-Czech 50: 269-275

WAGNER E, ARNDT R, HILTON B 2002: Physiological stress responses, egg survival and sperm motility for rainbow trout broodstock anaesthetized with clove oil, tricaine methanesulfonate or carbon dioxide. Aquaculture 211: 353-366

WATERSTRAT, PR 1999: Induction and recovery from anesthesia in channel catfish (Ictalurus punctatus) fingerlings exposed to clove oil. J World Aquacul Soc 30: 250- 255

YOSHIKAWA H, ISHIDA Y, UENO S, MITSUDA H 1988: Changes in depth of anesthesia of the carp anaesthetized with a constant level of carbon dioxide. Bull Jap Soc Sci Fish 54:457-462 